\title{
Penerapan Algoritma A-star dan Brute Force pada Aplikasi Jakvel (Jakarta Travel) Berbasis Android
}

\author{
Septi Andryana, Andrianingsih, Naif Farhan*
}

Fakultas Teknologi Komunikasi dan Informatika, Prodi Informatika, Universitas Nasional, Jakarta Selatan, Indonesia Email: ${ }^{1}$ septi.andryana@ civitas.unas.ac.id, ${ }^{2}$ andrianingsih@ civitas.unas.ac.id, 3," naiffarhan20@ gmail.com

Email Penulis Korespondensi: naiffarhan20@gmail.com

Abstrak-Kota Jakarta memiliki beberapa objek wisata utama yang menarik untuk dikunjungi. Sebagai Ibu Kota Negara Indonesia pastinya akan dilirik dan dikunjungi oleh wisatawan lokal maupun wisatawan mancanegara. Namun adanya keterbatasan informasi, wisatawan dari luar daerah Jakarta kurang memiliki informasi lengkap wisata yang ada di Kota Jakarta dan jalan yang harus di tempuh ke lokasi wisata, dikarenakan banyaknya jalan dan padatnya lalu lintas, hal ini menjadikan permasalahan ketika ingin berlibur ke Kota Jakarta. Maka dari itu penulis membuat rancangan aplikasi yang bernama Jakvel berbasis Android, aplikasi ini memberikan informasi dan mencari jalur terpendek ke lokasi wisata bagi wisatawan yang ingin berlibur ke Kota Jakarta. Pada penelitian ini menggunakan algoritma A-star dan Brute Force. Algoritma A-star akan diterapkan untuk pencarian jalur terpendek menuju lokasi wisata dan algoritma Brute Force digunakan dalam pencarian kata (string) dalam memilih wisata. Dengan adanya aplikasi ini diharapkan mempermudah wisatawan luar daerah Jakarta dalam mengetahui informasi wisata dan membantu pencarian jalur terpendek menuju lokasi yang ada di Kota Jakarta. Setelah dilakukannya pengujian dari 10 lokasi wisata untuk menentukan jalur terpendek dengan membandingkan algoritma A-star dengan Google Maps yang berbasis Android, dengan tingkat keberhasilannya 70\% dalam mencari jalur terpendek menggunakan algoritma Astar dan hasil pengujian pencarian string menggunakan algoritma Brute Force memiliki persentase 100\% akurat.

Kata Kunci: Algoritma A-Star; Wisata; Android; Google Maps; Algoritma Brute Force

\begin{abstract}
The city of Jakarta has several main tourist attractions that are interesting to visit. As the Capital of the State of Indonesia, it will certainly be ogled and visited by local and foreign tourists. However, there is limited information, tourists from outside the Jakarta area lack complete information on tourism in the city of Jakarta and the roads that must be taken to tourist sites, due to the number of roads and heavy traffic, this makes it a problem when you want to vacation in the city of Jakarta. Therefore, the author designed an application called Jakvel based on Android, this application provides information and looks for the shortest path to tourist sites for tourists who want to vacation in Jakarta. In this study using the A-star and Brute Force algorithms. The A-star algorithm will be applied to find the shortest path to tourist sites and the brute force algorithm is used to search for words (strings) in selecting tours. With this application, it is hoped that it will make it easier for tourists outside the Jakarta area to find out tourist information and help find the shortest path to locations in the city of Jakarta. After testing of 10 tourist sites to determine the shortest path by comparing the A-star algorithm with Google Maps based on Android, with a 70\% success rate in finding the shortest path using the A-star algorithm and the results of string search testing using the Brute Force algorithm have a percentage of $100 \%$ accurate.
\end{abstract}

Keywords: Algorithm A-Star; Tourist; Android; Google Maps; Algorithm Brute Force

\section{PENDAHULUAN}

Ibu Kota Negara Republik Indonesia yaitu DKI Jakarta memiliki beberapa destinasi wisata, wisatawan domestik dan wisatawan mancanegara dapat mengunjungi tempat wisata atau destinasi wisata yang menarik ketika sedang berlibur ke Jakarta [1]. Setiap kawasan Kota Jakarta pastinya memiliki tempat hiburan atau tempat wisata yang menarik. Beragam destinasi wisata yang ada di Jakarta menjadi pilihan yang tepat ketika ingin berliburan, seperti bangunan bersejarah, taman hiburan, kebun binatang, wisata laut, dan beberapa tempat hiburan lainnya. Tidak sedikit masyarakat dari luar daerah Jakarta mengetahui informasi dan jalan atau lokasi wisata, biasanya mereka akan kesulitan ketika ingin mencari tempat objek wisata yang ada di Jakarta, karena kurangnya informasi informasi wisata, lokasi wisata dan padatnya jalur lalu lintas, ini menjadikan sebuah permasalahan ketika ingin berlibur ke Kota Jakarta [2].

Oleh karena itu, perlu adanya aplikasi yang menyediakan informasi dan lokasi wisata. Penulis menawarkan aplikasi mobile dengan nama "Jakvel", fungsi dari aplikasi ini memberikan informasi objek wisata di DKI jakarta dan mencari jalur terpendek (shortest path). Dalam pencarian jalur terpendek dapat menjadikan solusi ketika dalam mencari suatu lokasi terdekat dengan melalui beberapa jalur [3].

Penelitian terdahulu telah membahas algoritma A-star dalam mencari jalur terpendek. Salah satunya dalam mencari rute terpendek menuju Puskesmas yang ada di DKI Jakarta. Hasil akhir dari pengujian telah mendapatkan rute terpendek sebesar $80 \%$ dengan menggunakan algoritma A-star [4].

Penelitian pencarian lokasi fotografi di Kota Bandar Lampung dan mencari jalur terpendek menuju tempat fotografi yang ada di bandar lampung. Fotografer memerlukan informasi jalur terpendek yang dapat mempermudah dalam pencarian tempat menarik. Hasil dari pencarian rute dalam mencari spot foto di Kota Bandar Lampung ini telah memberikan informasi lokasi yang akurat [5].

Penelitian terdahulu selanjutnya yaitu dalam mencari tempat kuliner di Kota Bandar Lampung menggunakan algoritma A-star, dibuatnya aplikasi dalam pencarian ini mampu memberikan informasi wisata kuliner dan rute terdekat. Setelah melakukan pengujian perhitungan manual maupun aplikasi dapat menghasilkan jarak yang valid yaitu $1.5 \mathrm{~km} \mathrm{[6].}$ 
Penelitian terdahulu dalam menggunakan algoritma A-star selanjutnya yaitu dalam mencari jalur terpendek dalam mencari tempat kuliner di Kecamatan Menes Banten. Pada penelitian ini telah menemukan jalur terdekat menuju tempat kuliner yang ada di Kecamatan Menes [7].

Kemudian penelitian terdahulu selanjutnya yaitu melakukan pencarian rute terdekat menggunakan algoritma A-star sehingga dapat menemukan rute ke rumah sakit yang ada di Kota Bogor. Dengan menerapkan algoritma A-star ini ke aplikasi maka dapat dengan mudah melihat pencarian dan memutuskan rute terpdek yang optimal ke lokasi rumah sakit yang ada di Bogor [8].

Dari penelitian-penelitan sebelumnya maka penulis akan membuat aplikasi berbasis Android yang bernama "Jakvel" menggunakan algoritma A-star dalam pencarian jalur terpendek. Tujuan dari aplikasi ini memudahkan pengguna untuk mengetahui informasi tempat wisata dan dapat menyelesaikan permasalahan dalam pencarian jalur terpendek menuju lokasi wisata yang ada di wilayah DKI Jakarta dan kelebihan dari aplikasi ini juga terdapat informasi atau deskripsi wisata yang lengkap sehingga tidak perlu mencari menggunakan aplikasi pihak ke-3.

\section{METODOLOGI PENELITIAN}

\subsection{Alur Penelitian}

Pada penelitian ini memiliki alur penelitian yang dilakukan untuk merancang sebuah aplikasi, berikut tahapantahapan dalam merancang aplikasi:

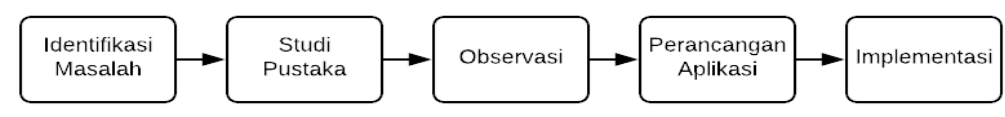

Gambar 1. Alur Penelitian

Pada gambar 1 terdapat proses tahapan pada penelitian, diantaranya yaitu:

a. Identifikasi Masalah

Tahapan awal dalam melakukan penelitian ini dilakukannya identifikasi masalah mengenai informasi wisata dan pencarian jalur terpendek ke objek wisata di DKI Jakarta.

b. Studi Pustaka

Tahapan selanjutnya yaitu studi pustaka, tahapan ini adalah tahapan dalam mencari informasi dan memahami materi yang diperoleh dari jurnal, buku, dan beberapa sumber dengan penelitian yang sejenis.

c. Observasi

Melakukan observasi dari hasil pengumpulan data. Dalam pengumpulan data untuk penelitian ini menggunakan data yang bersumber dari Google Maps, situs resmi Jakarta Tourismn, dan berbagai situs terpercaya dalam mencari data informasi wisata yang ada di Jakarta. Google menyediakan layanan yang dapat memudahkan para pengembang aplikasi, agar pengembang aplikasi bisa mengakses dengan menggunakan Google Maps API [9]. Data tersebut digunakan untuk menampilkan maps dan menampilkan lokasi.

d. Perancangan Aplikasi

Tahapan ini dilakukannya guna memudahkan tahapan selanjutnya yaitu pada tahapan implementasi, tahapan perancangan aplikasi ini merupakan proses pembuatan desain aplikasi dan alur aplikasi.

e. Implementasi

Tahapan terakhir ini merupakan suatu proses dari hasil perancangan yang sudah dimasukan kode program dan dilakukan implementasi algoritma A-star dan Brute Force. Algoritma A-star diterapkan untuk mencari jalur terpendek menuju lokasi wisata dan algoritma Brute Force diterapkan pada fitur pencarian kata atau string.

\subsection{Algoritma A-star}

Algoritma A-star merupakan sebuah algoritma untuk menentukan jalur terpendek dari titik awal ke titik tujuan. Salah satu metode pencarian yang mempunyai informasi yaitu algoritma A-star [10]. Algoritma A-star dibagi menjadi dua titik yaitu titik yang dapat dilalui (Open List) dan titik yang tidak dapat dilalui (Closed List) [11]. Jika Konsep pada algoritma A-star ini merupakan pencarian jalur dan grafik melintang, proses yang secara efisien di sebuah jalur melintang dengan titik-titik yaitu node [11]. Algoritma A-star ini memiliki nilai heuristik yang dijadikan sebagai dasar pengujian pemilihan rute dan menggunakan perkiraan jarak terdekat (cost) untuk mencapai tujuan [8]. Dalam perhitungan algoritma A-star dapat mengetahui biaya dan jarak terdekat yang akan dilewati [12]. Untuk meneyelsaikan masalahnya dapat dilakukan perhitungan menggunakan graf [13]. Berikut perthitungan yang digunakan dalam algoritma A-star:

$$
f(n)=g(n)+h(n)
$$

Dimana $\mathrm{f}(\mathrm{n})$ merupakan biaya perkiraan terendah, $\mathrm{g}(\mathrm{n})$ merupakan biaya dari node asal ke node $\mathrm{n}$, lalu selanjutnya h(n) merupakan biaya dari node asal ke node tujuan [14]. 


\subsection{Algoritma Brute Force}

Algoritma Brute Force merupakan pattern matching yang bersifat pencariannya left-to-right atau dari kiri ke kanan karena akan dicocokan huruf per huruf dalam sebuah teks, jika huruf dalam pattern tidak sesuai maka akan diulang pencarian sehingga menemukan teks yang cocok [15]. Algoritma Brute Force ini menjadikan solusi sebagai pemecahan masalah dalam melakukan pencocokan kata sehingga menjadi lebih optimal [16]. Pemecahan masalah pada algoritma Brute Force termasuk sederhana dan dengan cara yang jelas. Algoritma Brute Force mempunyai beberapa fungsi yaitu sebagai pemecahan masalah pencocokan string, pencarian, dan pengurutan [17].

\section{HASIL DAN PEMBAHASAN}

\subsection{Implementasi}

\section{a. Perhitungan Manual Algoritma A-star}

Pada saat implementasi, penulis melakukan perhitungan secara manual menggunakan graf dengan simpul awal sebagai lokasi penulis dan simpul tujuan sebagai kebun binatang ragunan, jalur graf sesuai dengan jalur alternatif pada Google Maps. Perhitungan secara manual ini dilakukan untuk melihat hasil dari pencarian jalur terpendek menuju lokasi wisata.

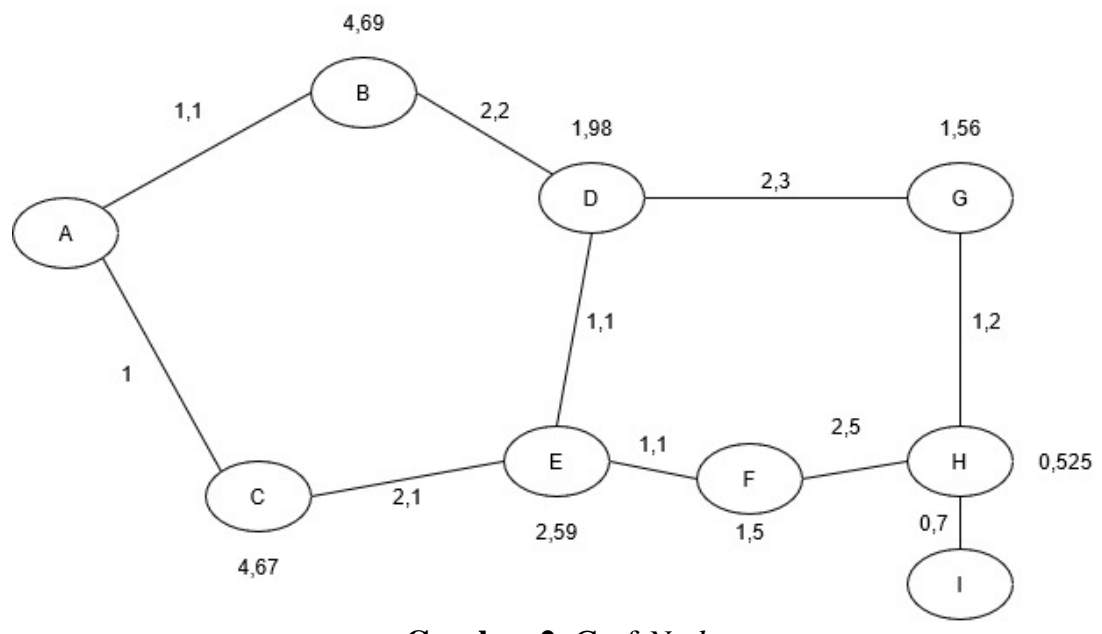

Gambar 2. Graf Node

Pada gambar 2 merupakan graf dalam mencari jalur terpendek menuju lokasi wisata. Graf tersebut di sertai simpul atau node yang saling terhubung. Graf tersebut menggambarkan jalur dengan titik awal (A) lokasi penulis dan lokasi tujuan yaitu tempat wisata Ragunan (I). Simpul yang saling terhubung ini merupakan nilai g(n) dengan jarak tempuh dalam bentuk satuan km dan setiap simpul memiliki nilai h(n) yaitu jarak garis lurus dari simpul $\mathrm{n}$ ke simpul tujuan. Nilai $\mathrm{g}(\mathrm{n})$ dan $\mathrm{h}(\mathrm{n})$ ini menggunakan data jarak dari Google Maps. Pada perhitungan graf ini dilakukan pencarian nilai $\mathrm{f}(\mathrm{n})$ terkecil untuk memilih jalur yang terpendek, nantinya perhitungan tersebut akan menentukan simpul yang masih memiliki peluang terpilih (Open List) dan simpul yang sudah terpilih maka akan masuk ke (Closed List) yang merupakan kumpulan dari simpul yang sudah pernah terpilih sebagai simpul terbaik.

Tabel 1. Perhitungan Algoritma A-star Simpul A - B dan A - C

\begin{tabular}{lll}
\hline Simpul & G(n) + H(n) & F(n) \\
\hline A - B & $1,1+4,69$ & 5,79 \\
A - C & $1+4,67$ & 5,67 \\
\hline
\end{tabular}

Proses pencarian nilai $\mathrm{f}(\mathrm{n})$ terkecil pada simpul A - B dan A - C dapat dilihat pada tabel 1. Simpul A merupakan simpul awal dengan kata lain simpul A akan masuk ke Closed List. Lalu melakukan proses perhitungan untuk mencari jalur terpendek dari setiap simpul. Simpul A - B melakukan perhitungan algoritma A-star dengan hasil 5,79 km dan A - C dengan hasil 5,67 km. Maka hasil f(n) terkecil adalah simpul C dan simpul C akan masuk Closed List dan E menjadi Open List.

Tabel 2. Perhitungan Algoritma A-star Simpul E - D dan E - F

\begin{tabular}{lll}
\hline Simpul & G(n) + H(n) & F(n) \\
\hline E - D & $1,1+1,98$ & 3,08 \\
E-F & $1,1+1,5$ & 2,6 \\
\hline
\end{tabular}


ISSN 2614-5278 (media cetak), ISSN 2548-8368 (media online)

Available Online at https://ejurnal.stmik-budidarma.ac.id/index.php/mib DOI 10.30865/mib.v5i3.3089

Pada tahap perhitungan berikutnya yaitu simpul E - D dan E - F dapat dilihat pada tabel 2. Hasil dari perhitungan simpul E - F nilainya lebih kecil yaitu 2,6 km yang berarti akan melalui ke simpul F sebagai Open List. Lalu simpul E akan masuk kedalam Closed List. Lalu pada simpul F hanya ada satu jalur yaitu simpul $\mathrm{H}$ yang artinya simpul F akan masuk ke Closed List.

Tabel 3. Perhitungan Algoritma A-star Simpul H - G dan H - I

\begin{tabular}{lll}
\hline Simpul & G(n) + H(n) & F(n) \\
\hline $\mathrm{H}-\mathrm{G}$ & $1,2+1,56$ & 2,76 \\
$\mathrm{H}-\mathrm{I}$ & $0,7+0$ & 0,7 \\
\hline
\end{tabular}

Setelah itu melakukan perhitungan simpul H - G dan H - I dapat dilihat pada tabel 3. Hasil nilai $\mathrm{f}(\mathrm{n})$ terkecil yaitu pada simpul $\mathrm{H}$ - I dengan nilai $0,7 \mathrm{~km}$. Simpul $\mathrm{H}$ - I yang artinya sudah sampai tujuan maka simpul $\mathrm{H}-\mathrm{I}$ masuk kedalam Closed List. Jadi pencarian jalur terpendek pada graf yaitu simpul A - C - E - F - H - I dengan jarak $6,6 \mathrm{~km}$. Jarak dari perhitungan manual dengan aplikasi Jakvel berbeda $0,1 \mathrm{~km}$, yaitu jarak aplikasi mencapai $6.7 \mathrm{~km}$ dari lokasi penulis menuju tempat wisata Ragunan.

\section{b. Penerapan Algoritma Brute Force}

Pada gambar 3 ini merupakan tampilan ketika pengguna mencari destinasi wisata yang ingin dikunjungi dengan fitur navigasi "search" menggunakan algoritma Brute Force. Fitur ini memudahkan pengguna dalam mencari kata destinasi wisata yang akan dikunjungi pengguna.

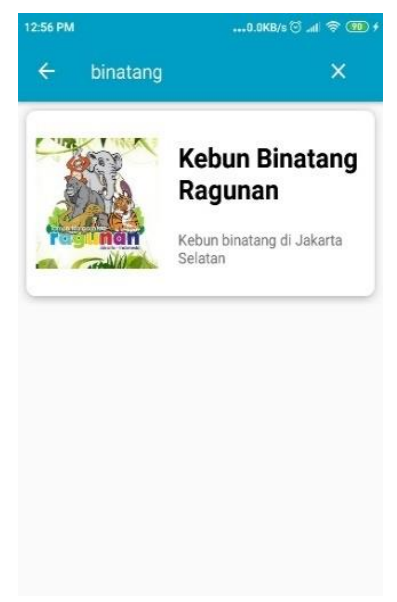

Gambar 3. Pencarian String

Pada gambar 4 merupakan ilustrasi cara kerja algoritma Brute Force, yang membandingkan satu-persatu huruf pada teks dan di pattern atau pola dari kiri ke kanan. Seperti pada langkah kedua dalam mencocokan huruf o dengan $\mathrm{m}$, terlihat huruf o tidak cocok dengan huruf $\mathrm{m}$, maka akan dilanjutkan ke proses berikutnya sehingga menemukan huruf yang cocok seperti pada langkah keenam. Algoritma Brute Force pada aplikasi Jakvel ini digunakan untuk pencarian kata ketika sedang memilih lokasi wisata pada navigasi pencarian.

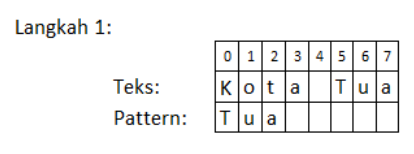

Langkah 2:

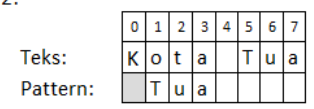

Langkah 3:

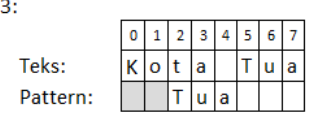

Langkah 4:

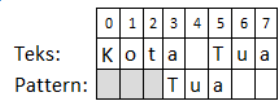

Langkah 5:

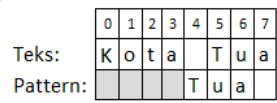

Langkah 6:

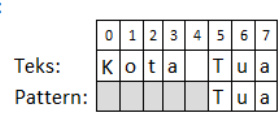

Gambar 4. Cara Kerja Brute Force

Tabel 4. Hasil Pengujian Pencarian String

\begin{tabular}{lll}
\hline \multicolumn{1}{c}{ Input } & \multicolumn{1}{c}{ Output } & \multicolumn{1}{c}{ Hasil } \\
\hline Binatang & Binatang & $100 \%$ Akurat \\
Ancol & Ancol & $100 \%$ Akurat \\
Monas & Monas & $100 \%$ Akurat \\
Kota & Kota & $100 \%$ Akurat
\end{tabular}


ISSN 2614-5278 (media cetak), ISSN 2548-8368 (media online)

Available Online at https://ejurnal.stmik-budidarma.ac.id/index.php/mib DOI 10.30865/mib.v5i3.3089

\begin{tabular}{lll}
\hline \multicolumn{1}{c}{ Input } & \multicolumn{1}{c}{ Output } & \multicolumn{1}{c}{ Hasil } \\
\hline Babakan & Babakan & $100 \%$ Akurat \\
Mini & Mini & $100 \%$ Akurat \\
Mangrove & Mangrove & $100 \%$ Akurat \\
Planetarium & Planetarium & $100 \%$ Akurat \\
Kidzania & Kidzania & $100 \%$ Akurat \\
Waterbom & Waterbom & $100 \%$ Akurat \\
\hline
\end{tabular}

Pada tabel 4 merupakan hasil pengujian dari pencocokan string menggunakan algoritma Brute Force. Pengujian ini menggunakan 10 kata dari beberapa kata dalam nama wisata yang sudah ada di dalam daftar menu pilih wisata.

Untuk tingkat keberhasilan dalam mencari string menggunakan algoritma Brute Borce memiliki persentase 100\%. Dalam pencarian string menggunakan algoritma Brute Force terbukti akurat sehingga dapat memudahkan pengguna dalam mencari kata pada fitur navigasi "search".

\subsection{Use Case Diagram}

Use case diagram mempresentasikan skenario pengguna dengan sistem. Pada gambar 5 merupakan tampilan use case diagram dari aplikasi Jakvel. Tahap awal penggunaan aplikasi, pengguna dapat memilih menu daftar wisata, tentang, dan bantuan. Ketika pengguna memilih menu daftar wisata maka akan menampilkan pilihan wisata. Lalu setelah pengguna sudah memilih wisata maka akan menampilkan deskripsi wisata, setelah itu pengguna dapat melihat lokasi wisata pada tampilan maps.

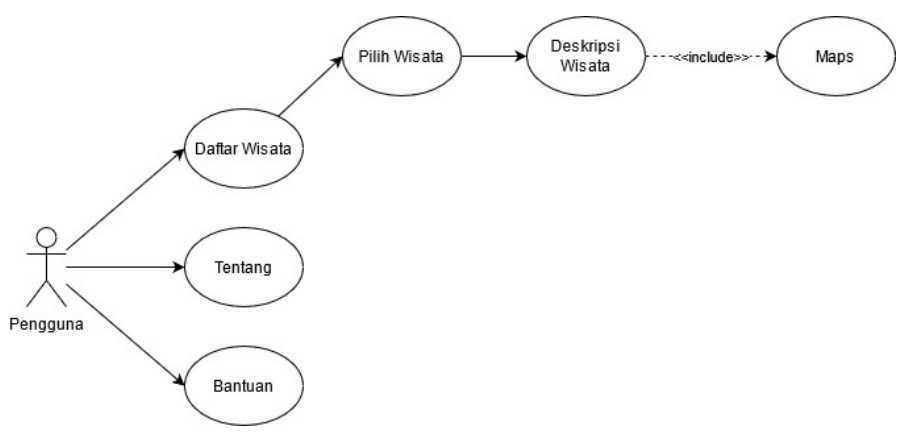

Gambar 5. Use Case Diagram Aplikasi

\subsection{Tampilan Aplikasi}

Hasil penelitian dari perancangan yang telah dilakukan, maka penulis membangun sebuah aplikasi Android yang bernama Jakvel. Aplikasi Jakvel ini memberikan informasi wisata dan jalur terpendek menuju lokasi wisata Kota Jakarta.

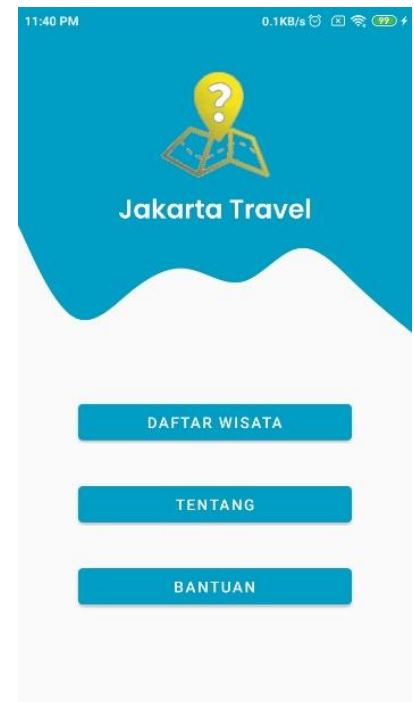

Gambar 6. Tampilan Menu Utama

Tampilan menu utama aplikasi dapat dilihat pada gambar 6. Tampilan dari menu utama ini terdiri dari logo aplikasi, menu daftar wisata, menu tentang, dan menu bantuan. Tombol menu "daftar wisata" ini menampilkan beberapa pilihan wisata jakarta. Tombol menu tentang dan bantuan ini merupakan informasi dalam menggunalan aplikasi dan latar belakang aplikasi. 
JURNAL MEDIA INFORMATIKA BUDIDARMA

Volume 5, Nomor 3, Juli 2021, Page 879-887

ISSN 2614-5278 (media cetak), ISSN 2548-8368 (media online)

Available Online at https://ejurnal.stmik-budidarma.ac.id/index.php/mib DOI 10.30865/mib.v5i3.3089

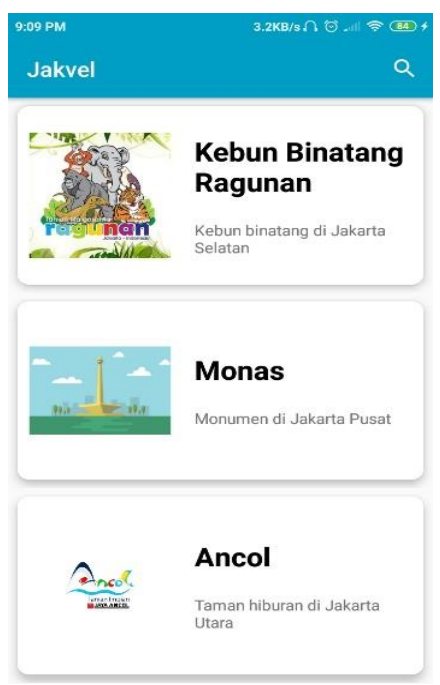

Gambar 7. Tampilan Menu Pilih Wisata

Tampilan dari beberapa pilihan destinasi wisata Kota Jakarta bisa di lihat pada pada gambar 7. Dalam bagian menu ini juga terdapat navigasi "search" yang berfungsi dalam mencari kata untuk memudahkan pengguna dalam mencari destinasi wisata yang ingin di kunjungi.

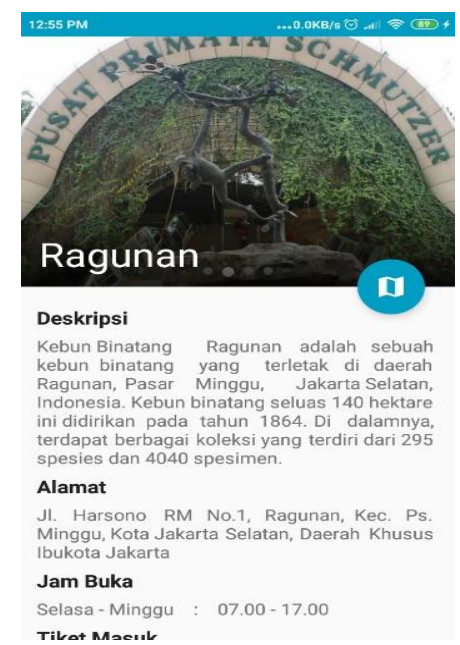

Gambar 8. Tampilan Informasi Wisata

Pada gambar 8 merupakan tampilan dari informasi ketika pengguna sudah memilih destinasi wisata yang dipilih. Pada bagian ini juga terdapat informasi deskripsi, alamat, jam buka, tiket masuk, tiket wahana, dll. Tombol yang berada di bagian kanan itu merupakan tombol untuk melihat jalur terpendek dari lokasi pengguna sampai lokasi wisata yang di pilih.

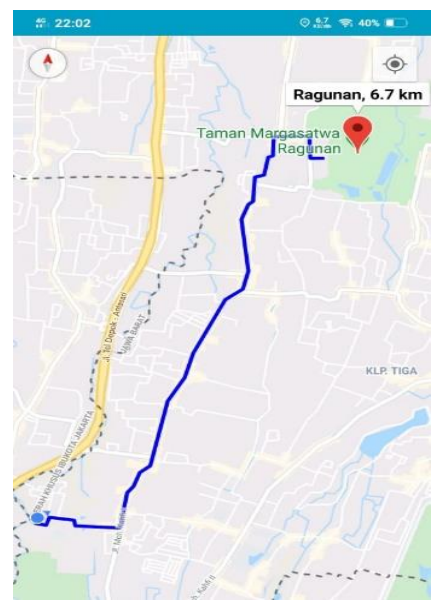

Gambar 9. Menampilkan Jalur Lokasi Wisata 


\section{JURNAL MEDIA INFORMATIKA BUDIDARMA}

Volume 5, Nomor 3, Juli 2021, Page 879-887

ISSN 2614-5278 (media cetak), ISSN 2548-8368 (media online)

Available Online at https://ejurnal.stmik-budidarma.ac.id/index.php/mib DOI 10.30865/mib.v5i3.3089

Tampilan dari jalur terpendek menuju lokasi wisata menggunakan algoritma A-star bisa dilihat pada gambar 9. Pengguna dapat menekan tombol current location yang berada di bagian kanan atas yang berfungsi sebagai melihat titik koordinat pengguna. Pengguna juga dapat melihat nama wisata yang di pilih dan juga dapat melihat berapa $\mathrm{km}$ yang harus di tempuh dari lokasi pengguna menuju tujuan.

\subsection{Hasil Perbandingan Algoritma A-star Dengan Google Maps}

Pada penelitian ini melakukan perbandingan dari aplikasi Jakvel dengan Google Maps yang berbasis Android. Pada tabel 5 merupakan koordinat titik awal dalam pengujian mencari jalur terpendek menuju lokasi wisata. Koordinat awal ini merupakan lokasi penulis untuk memastikan keakuratan dalam mencari jalur. Terdapat juga koordinat tempat wisata di Kota Jakarta pada tabel 6.

Tabel 5. Koordinat Awal

\begin{tabular}{lc}
\hline & Koordinat Awal \\
\hline Garis Lintang & -6.350950154525916 \\
Garis Bujur & 106.79464834157433 \\
\hline
\end{tabular}

Tabel 6. Koordinat Tempat Wisata

\begin{tabular}{lcc}
\hline \multirow{2}{*}{\multicolumn{1}{c}{ Nama Wisata }} & \multicolumn{2}{c}{ Koordinat Wisata } \\
\cline { 2 - 3 } & Garis Lintang & Garis Bujur \\
\hline Kebun Binatang Ragunan & -6.312458601966563 & 106.82018631155766 \\
Taman Impian Jaya Ancol & -6.129318994780803 & 106.8334230850355 \\
Monumen Nasional & -6.175381728949906 & 106.8271527968481 \\
Kota Tua & -6.135169827252432 & 106.81329829251618 \\
Setu Babakan & -6.339863462134931 & 106.82547675199184 \\
Taman Mini Indonesia Indah & -6.30244528485016 & 106.8951551505119 \\
Taman Wisata Alam Mangrove & -6.105331888709394 & 106.73558376582999 \\
Planetarium & -6.190082871033705 & 106.83885282360113 \\
Kidzania & -6.225072811852548 & 106.8097137706016 \\
Waterbom PIK & -6.11365589557312 & 106.74785959684782 \\
\hline
\end{tabular}

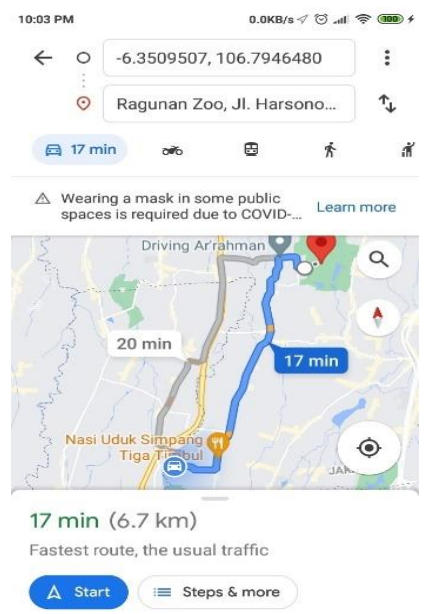

Gambar 10. Tampilan Jalur Google Maps

Pada gambar 10 merupakan tampilan dari aplikasi Google Maps. Titik awal yaitu koordinat penulis dan untuk titik tujuan yaitu koordinat tempat wisata, dapat dilihat pada tabel 4 dan tabel 5. Tujuan dari memakai koordinat pada aplikasi Google Maps ini ialah untuk menyerupai koordinat yang sama pada aplikasi Jakvel.

Tabel 7. Hasil Pengujian Jalur Terpendek

\begin{tabular}{lccc}
\hline \multicolumn{1}{c}{ Nama Wisata } & Algoritma A-star & Google Maps & Selisih Jarak \\
\hline Kebun Binatang Ragunan & $6.7 \mathrm{~km}$ & $6.7 \mathrm{~km}$ & $0 \mathrm{~km}$ \\
Taman Impian Jaya Ancol & $35.9 \mathrm{~km}$ & $36 \mathrm{~km}$ & $0.1 \mathrm{~km}$ \\
Monumen Nasional & $24.1 \mathrm{~km}$ & $24 \mathrm{~km}$ & $0.1 \mathrm{~km}$ \\
Kota Tua & $34.6 \mathrm{~km}$ & $35 \mathrm{~km}$ & $0.4 \mathrm{~km}$ \\
Setu Babakan & $4.8 \mathrm{~km}$ & $4.8 \mathrm{~km}$ & $0 \mathrm{~km}$ \\
Taman Mini Indonesia Indah & $21.2 \mathrm{~km}$ & $21 \mathrm{~km}$ & $0.1 \mathrm{~km}$
\end{tabular}


ISSN 2614-5278 (media cetak), ISSN 2548-8368 (media online)

Available Online at https://ejurnal.stmik-budidarma.ac.id/index.php/mib DOI 10.30865/mib.v5i3.3089

\begin{tabular}{lccc}
\hline \multicolumn{1}{c}{ Nama Wisata } & Algoritma A-star & Google Maps & Selisih Jarak \\
\hline Taman Wisata Alam Mangrove & $33.9 \mathrm{~km}$ & $34 \mathrm{~km}$ & $0.1 \mathrm{~km}$ \\
Planetarium & $23.8 \mathrm{~km}$ & $24 \mathrm{~km}$ & $0.2 \mathrm{~km}$ \\
Kidzania & $17.1 \mathrm{~km}$ & $18 \mathrm{~km}$ & $0.9 \mathrm{~km}$ \\
Waterbom PIK & $35.1 \mathrm{~km}$ & $35 \mathrm{~km}$ & $0.1 \mathrm{~km}$ \\
\hline
\end{tabular}

Hasil dari pengujian algoritma A-star dengan Google Maps Android dilihat pada tabel 7. Pengujian tersebut dilakukan sebanyak 10 lokasi destinasi wisata yang ada di Jakarta. Dengan menggunakan algoritma A-star telah berhasil mencari jalur terpendek sebanyak 7 lokasi dan 3 lokasi yang menunjukan jarak sedikit lebih pendek dengan menggunakan Google Maps. Untuk selisih jarak dari pencarian jalur terpendek menggunakan algoritma A-star dengan selisih jarak terbesar $0.9 \mathrm{~km}$ lebih pendek dibandingkan dengan Google Maps dan untuk selisih jarak terpendek menggunakan Google Maps yaitu dengan rata-rata $0.1 \mathrm{~km}$. Tingkat keberhasilan dari pengujian aplikasi dengan pencarian jalur terpendek menggunakan algoritma A-star menuju lokasi wisata yaitu dengan persentase sebesar $70 \%$. Sehingga dapat diketahui dalam pencarian jalur terpendek menggunakan algoritma Astar telah berhasil.

\section{KESIMPULAN}

Aplikasi Jakvel merupakan aplikasi yang menyedia informasi wisata yang ada di Kota Jakarta. Dengan menerapkan algoritma A-star pada aplikasi ini dapat mencari jalur terpendek dengan tujuan lokasi wisata yang ada di Kota Jakarta. Penggunaan aplikasi ini digunakan dari lokasi pengguna agar dapat digunakan dimanapun dan kapanpun. Aplikasi ini juga menggunakan algoritma Brute Borce dalam mencari kata untuk memudahkan pengguna dalam mencari destinasi wisata yang ingin di kunjungi. Berdasarkan hasil dari pengujian yang telah dilakukan maka bisa disimpulkan bahwa pencarian jalur terpendek menggunakan algoritma A-star menghasilkan persentase sebesar 70\%, pengujian menggunakan algoritma A-star ini berhasil 7 lokasi dari 10 lokasi yang telah melewati tahap pengujian dengan membandingkan jalur Google Maps berbasis Android. Untuk pengujian pencarian kata menggunakan algoritma Brute Force menghasilkan output yang diinginkan yaitu dengan persentase sebesar $100 \%$.

\section{REFERENCES}

[1] D. Marcelina and E. Yulianti, "Aplikasi Pencarian Rute Terpendek Lokasi Kuliner Khas Palembang Menggunakan Algoritma Euclidean Distance Dan a*(Star)," J. Sisfokom (Sistem Inf. dan Komputer), vol. 9, no. 2, p. 195, 2020, doi: 10.32736/sisfokom.v9i2.827.

[2] M. Mukhlis, M. Orisa, and F. . Ariwibisono, "Penerapan Algoritma a* Untuk Mencari Jarak Terdekat Tempat Wisat Kota Malang Raya,” JATI (Jurnal Mhs. Tek. Inform., vol. 4, no. 1, pp. 349-355, 2020, doi: 10.36040/jati.v4i1.2316.

[3] B. Pratama and A. T. Priandika, "Sistem Informasi Location Based Service Sentra Keripik Kota Bandar Lampung Berbasis Android," J. Teknol. dan Sist. Inf., vol. 1, no. 1, pp. 81-89, 2020, [Online]. Available: http://jim.teknokrat.ac.id/index.php/sisteminformasi/article/view/237.

[4] V. Budiman, Y. S. H. Lesmono, and H. Agung, "Aplikasi Berbasis Android Untuk Mencari Lokasi Puskesmas Terdekat Dengan Algoritma a-Star Di Provinsi Dki Jakarta,” J. Sist. Informasi, Teknol. Inform. dan Komput., vol. Vol.9, no. No.1, pp. 39-48, 2018

[5] Y. Fernando, M. A. Mustaqov, and D. A. Megawaty, "Penerapan Algoritma a-Star Pada Aplikasi Pencarian Lokasi Fotografi Di Bandar Lampung Berbasis Android,” J. Teknoinfo, vol. 14, no. 1, p. 27, 2020, doi: 10.33365/jti.v14i1.509.

[6] S. Purnama, D. A. Megawaty, and Y. Fernando, "Penerapan Algoritma A Star Untuk Penentuan Jarak Terdekat Wisata Kuliner di Kota Bandarlampung," J. Teknoinfo, vol. 12, no. 1, p. 28, 2018, doi: 10.33365/jti.v12i1.37.

[7] R. Rizky, T. Hidayat, A. H. Nugroho, and Z. Hakim, "Implementasi Metode A*Star Pada Pencarian Rute Terdekat Menuju Tempat Kuliner di Menes Pandeglang Banten," Geodika J. Kaji. Ilmu dan Pendidik. Geogr., vol. 4, no. 1, pp. 85-94, 2020, doi: 10.29408/geodika.v4i1.2068.

[8] Erniyati and Mulyati, "Di Kota Bogor Dengan Menggunakan Algoritma a *," Komputasi vol. 16, no. 1, pp. 245-253, 2019.

[9] A. Hermawan and A. S. Tiwa, "Penerapan Algoritma A-Star untuk Pencarian Tempat Kuliner di Kota Tangerang," pp. 104-114, 2021, doi: 10.30864/jsi.v15i2.335.

[10] R. Umar, A. Yudhana, and A. Prayudi, "Analisis Perbandingan Algoritma Djikstra, A-Star, dan Floyd Warshall dalam Pencarian Rute Terdekat pada Objek Wisata Kabupaten Dompu," J. Teknol. Inf. dan Ilmu Komput., vol. 8, no. 2, p. 227, 2021, doi: 10.25126/jtiik.0812866.

[11] I. B. Gede Wahyu Antara Dalem, "Penerapan Algoritma A* (Star) Menggunakan Graph Untuk Menghitung Jarak Terpendek," J. Resist. (Rekayasa Sist. Komputer), vol. 1, no. 1, pp. 41-47, 2018, doi: 10.31598/jurnalresistor.v1i1.253.

[12] M. Mayadi and R. Azhar, "Perbandingan Perhitungan Manual Dengan Algoritma a Star Dalam Pencarian Jalur Terpendek Untuk Pengiriman Pesanan Dodol Khas Lombok," J. Inform. dan Rekayasa Elektron., vol. 2, no. 2, p. 27, 2019, doi: $10.36595 /$ jire.v2i2.114.

[13] W. Alfarisi, "Pencarian Jalur Terpendek Pengirima N Barang Menggunakan Algoritma A* Studi Kasus Kantor POS Besar Medan)," JURIKOM (Jurnal Ris. Komputer), vol. 3, no. 1, pp. 90-95, 2016, [Online]. Available: http://dx.doi.org/10.30865/jurikom.v3i1.58. 
ISSN 2614-5278 (media cetak), ISSN 2548-8368 (media online)

Available Online at https://ejurnal.stmik-budidarma.ac.id/index.php/mib DOI 10.30865/mib.v5i3.3089

[14] A. P. U. Siahaan, "Implementation of A-Star Algorithm in Determining the Shortest Path on Graph," pp. 374-378, 2018, doi: 10.31227/osf.io/vprzu.

[15] C. Irawan and M. R. Pratama, "Perbandingan Algoritma Boyer-Moore dan Brute Force pada Pencarian Kamus Besar Bahasa Indonesia Berbasis Android," BIOS J. Teknol. Inf. dan Rekayasa Komput., vol. 1, no. 2, pp. 54-60, 2021, doi: 10.37148/bios.v1i2.13.

[16] R. Rismayani, N. Sambo Layuk, S. Wahyuni, H. Wali, and N. K. Marselina, "Pencarian Kata Pada Aplikasi Kamus Istilah Komputer dan Informatika Menggunakan Algoritma Brute Force Berbasis Android," Komputika J. Sist. Komput., vol. 10, no. 1, pp. 43-52, 2021, doi: 10.34010/komputika.v10i1.3644.

[17] B. W. Santoso, F. Sundawa, and M. Azhari, "Implementasi Algoritma Brute Force Sebagai Mesin Pencari ( Search Engine ) Berbasis Web Pada Database," J. Sisfotek Glob., vol. 6, no. 1, pp. 1-8, 2016, [Online]. Available: https://core.ac.uk/download/pdf/288088999.pdf. 